\section{Military Technical College Kobry El-Kobbah, Cairo, Egypt.}

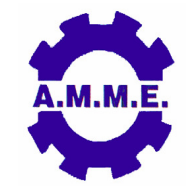

\title{
PREDICTION OF WHEEL NUMERIC FOR SANDY-TIRE
}

\author{
A. Hendy ${ }^{*}$ S. Hegazy ${ }^{\star}$, A. Abdel-Bary*, M.A. Emam ${ }^{\star \star}$ and Y. Hendawy ${ }^{\star \star \star}$
}

\begin{abstract}
The various techniques for evaluating the wheel numeric and vehicle performance have been studied. The wheel numeric depends on many parameters; vehicle weight, tire geometry, and soil strength in terms of cone index. The tire geometry includes tire width, tire diameter, section height and tire deformation. The tire deflection is very difficult to accurately measure. So the main purpose of this paper is to develop a new wheel numeric formula with a new parameter depending on the inflation pressure inside the tire instead of the tire deflection.
\end{abstract}

A theoretical study to investigate the effect of soil cone index, tire geometry and vehicle weight on different wheel numeric has been carried out and so their effects on the vehicle performance have been carried out. The performance of off road vehicle on soft soil in terms of rolling resistance, drawbar pull and tractive efficiency has been studied and investigated using variety of methods. These include; theoretical, semi-empirical and empirical methods based on wheel mobility number. The results showed that the new numeric formula gives a good correlation with published results at different soil cone index, vehicle weight, tire width, tire diameter and tire inflation pressure. Also the predicted performance has a good agreement with published experimental results at same conditions.

\section{KEY WORDS}

Off-road vehicle performance, wheel numeric number, inflation pressure.

\footnotetext{
* Egyptian Armed Forces.

** Associate professor, College of Engineering, Helwan University.

*** Professor, Higher Institute of Technology, 10th of Ramadan City.
} 


\section{NOMENCLATURE}

\begin{tabular}{|c|c|}
\hline b & Tire section width [m] \\
\hline $\mathrm{Cl}$ & Cone index, $\left[\mathrm{kN} / \mathrm{m}^{2}\right]$ \\
\hline $\begin{array}{l}\mathrm{C}_{\mathrm{n}}, \\
\mathrm{N}_{\mathrm{c}}, \mathrm{N}_{\mathrm{Cl}}, \mathrm{B}_{\mathrm{n}}, \mathrm{N}_{\mathrm{R}}, \mathrm{N}_{\mathrm{m}}\end{array}$ & Wheel numeric (wheel mobility numbers) \\
\hline $\mathrm{C}_{\mathrm{nn}}$ & New wheel numeric \\
\hline d & Overall tire diameter [m] \\
\hline G & Cone index gradient \\
\hline $\mathrm{h}$ & Tire section height $[\mathrm{m}]$ \\
\hline $\mathrm{k}$ & Constant (fit parameter) \\
\hline $\mathrm{k}_{\mathrm{c}}$ & Soil deformation modulus for cohesive components $\left[\mathrm{kN} / \mathrm{m}^{\mathrm{n}+1}\right]$ \\
\hline $\mathrm{k}_{\varphi}$ & Soil deformation modulus for frictional components $\left[\mathrm{kN} / \mathrm{m}^{\mathrm{n}+2}\right]$ \\
\hline $\mathrm{n}$ & Sinkage exponent \\
\hline NT & Net Traction, [kN] \\
\hline NTR & Net Traction Ratio \\
\hline$P$ & Pull force, [kN] \\
\hline$P_{i}$ & Inflation pressure [kPa] \\
\hline $\mathrm{RR}$ & Rolling resistance, [kN] \\
\hline r & Rolling radius [m] \\
\hline TDF & Tire deflection factor \\
\hline TE & Tractive efficiency \\
\hline W & Weight on tire, [kN] \\
\hline$W_{r}$ & Nominal tire load, (rated tire load) $[\mathrm{kN}]$ \\
\hline $\mathrm{W}_{\mathrm{TW}}$ & Vehicle weight, [kN] \\
\hline z & Sinkage $[\mathrm{m}]$ \\
\hline$\mu_{\mathrm{mrr}}$ & Motion rolling resistance ratio \\
\hline$\mu_{\mathrm{tr}}$ & Torque ratio \\
\hline$\mu_{\mathrm{ntr}}$ & Net traction ratio \\
\hline$\mu_{n^{\max }}$ & maximum coefficient of net traction ratio \\
\hline$\delta$ & Tire deflection [m] \\
\hline$\theta$ & Moisture content \\
\hline
\end{tabular}

\section{ABBREVIATION}

WES

Waterways Experiment Station 


\section{INTRODUCTION}

The first steps in the development of a method for evaluating the off road vehicle performance consists of experimental testing of tires on natural terrain surfaces to develop approximate relations between vehicle performance and terrain conditions, many relations have been proposed to predict the tire dimensionless performance. The analytical approach is concerned with predicting the performance of a traction device. The distribution of normal and shear stress at the soil-tire/track interface and the geometry of the 3-D contact surface must be determined. There are two other approaches; empirical and semi-empirical. The empirical approach is based on the cone index for predicting the mobility of vehicles by dimensionless tire performance coefficients (the main task in this paper). The semi-empirical approach involved in measuring soil deformation parameters then calculating the shear-stress. The shear deformation of the soil under a traction device is assumed to be similar to the shear generated by a torsion shear device. Bekker [1-2] assumed the normal stress under a flat plate depends on sinkage, plate width and soil coefficient.

Freitag [3] developed the first dimensionless wheel numeric and empirical mobility models based on wheel numeric. The wheel performance was measured at different weight on standard soils using soil bin and test lanes on terrain. Turnage [4] developed the method further, and presented separate methods for determining the soil properties for friction and cohesion soils and the corresponding mobility models. For cohesion soil the author used an average cone index, and a cone index gradient for the friction soils. Wismer \& Luth [5] combined mobility models with soil shear model and included the slip into mobility models. This model became one kind of basic mobility model for several later researches. Gee-Glough [6-7] found out, that soil shear strength was somewhat correlated with penetration resistance, and added a soil shear factor into the model. Brixius [8-9] developed a more generalized expression for tractive characteristics of bias-ply pneumatic tires. The approach is based on a modified mobility number. Maclaurin [10-13] studied the influence of soil surface properties and tire patterns on wheel performance using WES-method as a frame of reference. Rowland [14], Rowland and Peel [15], developed WES modeling depending on a new wheel numeric, and extended it also for tracked vehicles. The author presented the concept of mean maximum pressure MMP, which is the maximum allowable calculated soil contact pressure at no-go situation. Several authors in different countries have used available models, or presented improved versions of empirical mobility models using penetrometer resistance as soil parameter.

\section{WHEEL NUMERIC}

The Wheel numeric is a dimensionless variable calculated using a special formula, which includes tire and soil parameters. Different authors have proposed different empirical Wheel numeric models for determining the best fitting combinations of tire dimensions and deflection with observed tire performance. The wheel numeric concept was first derived by Freitage [3] one for clay and the other for sand soil. The wheel performance was measured at different weight on standard soils, using on soil bin and test lanes on terrain. 
For clay

For sand

$$
\mathrm{N}_{\mathrm{c}}=\frac{\mathrm{CI} \mathrm{bd}}{\mathrm{W}} \sqrt{\frac{\delta}{\mathrm{h}}}
$$

$$
\mathrm{N}_{\mathrm{s}}=\frac{\mathrm{G}(\mathrm{b} \cdot \mathrm{d})^{3 / 2}}{\mathrm{~W}} \cdot \frac{\delta}{\mathrm{h}}
$$

Turnage [16-18] developed the method further, and presented separate methods for determining the soil properties for friction and cohesion soils and the corresponding mobility models. For cohesion soil the author used an average cone index, and a cone index gradient for the friction soils. The most empirical relationships to predict the vehicle traction are based on this wheel numeric:

$$
\mathrm{N}_{\mathrm{CI}}=\frac{\mathrm{CI} \mathrm{bd}}{\mathrm{W}} \sqrt{\frac{\delta}{\mathrm{h}}} \cdot \frac{1}{1+\frac{\mathrm{b}}{2 \cdot d}}
$$

Wismer and Luth [5] combined mobility models with soil shear model and included the slip into mobility models. This model became one kind of basic mobility model for several later research offices using a simple wheel numeric:

$$
\mathrm{C}_{\mathrm{n}}=\frac{\mathrm{CI} \mathrm{bd}}{\mathrm{W}}
$$

Brixius [6-7] developed a more generalized expression for tractive characteristics of bias-ply pneumatic tires. The approach is based on a modified wheel numeric:

$$
\mathrm{B}_{\mathrm{n}}=\frac{\mathrm{CI} \mathrm{bd}}{W}\left(\frac{1+\frac{5 \delta}{\mathrm{h}}}{1+\frac{3 \mathrm{~b}}{\mathrm{~d}}}\right)
$$

Rowland, D \& Peel, J. W. [15] proposed a wheel numeric, used for determining the MMP, with similar results:

$$
\mathrm{N}_{\mathrm{R}}=\frac{\mathrm{Cl} \cdot \mathrm{b}^{0.85} \cdot \mathrm{d}^{\mathrm{L} 1.15}}{\mathrm{~W}} \sqrt{\frac{\delta}{\mathrm{h}}}
$$

Maclaurin [12-14] studied the influence of soil surface properties and tire patterns on wheel performance, and he concluded that a weak surface layer decreases the wheel performance, and that the influence of the surface layer becomes more pronounced with the use of special terrain tires. The factor $\delta / h$ replaced by $\delta / d$, which is easier to use without affecting the accuracy of the model. He presented somewhat simpler wheel mobility number, $\mathrm{Nm}$, which seemed to give the best estimates. 


$$
\mathrm{N}_{\mathrm{m}}=\frac{\mathrm{CI} \cdot \mathrm{b}^{0.8} \mathrm{~d}^{0.8} \delta^{0.4}}{W}
$$

Several authors in different countries have used available models, or presented improved versions of empirical mobility models using penetrometer resistance as soil parameter.

Each one developed empirical relationships between tractive performance parameters and the above wheel numeric which are found.

\section{WHEEL NUMERIC INVESTIGATION BASED ON TIRE INFLATION PRESSURE (CASE STUDY)}

A case study of a real test wheel data for Jeep off road 750-R16 from Abdel-Bary [19-20] has been done for examining the wheel numeric's according the effect of their parameters $(\mathrm{Cl}, \mathrm{b}, \mathrm{d}, \mathrm{W}, \mathrm{h}, \delta)$. The tire was tested under different load and at different inflation pressure. The tire width, height, diameter and deflection were measured in Table (1). A theoretical study of the parameters $(\mathrm{Cl}, \mathrm{b}, \mathrm{d}, \mathrm{W}, \mathrm{h}, \delta)$ as an independent variables [26] is investigated.

Table (1): Experimental tire testing at various loads and inflation pressures [2].

\begin{tabular}{|c|c|c|c|c|c|c|}
\hline Tire size & $\begin{array}{c}\text { Inflation } \\
\text { pressure } \\
\mathbf{P i}[\mathrm{kPa}]\end{array}$ & $\begin{array}{c}\text { Vertical } \\
\text { load } \\
\mathbf{W}[\mathrm{kN}]\end{array}$ & $\begin{array}{c}\text { Tire } \\
\text { width } \\
\mathbf{b}[\mathrm{mm}]\end{array}$ & $\begin{array}{c}\text { Tire } \\
\text { diameter } \\
\mathbf{d}[\mathbf{m m}]\end{array}$ & $\begin{array}{c}\text { Tire sec. } \\
\text { height } \\
\mathbf{h}[\mathbf{m m}]\end{array}$ & $\begin{array}{c}\text { Tire } \\
\text { deflection } \\
\mathbf{\delta}[\mathrm{mm}]\end{array}$ \\
\hline $750-16$ & $100-250$ & $2-7$ & $205-226$ & $657-776$ & $125-180$ & $0-25$ \\
\hline
\end{tabular}

\section{(a) Effect of soil strength}

The soil cone index is varied from 400 to $600 \mathrm{kPa}$ and all other parameters are fixed in Equations 1-7. The effect of soil strength in terms of cone index on all wheel numeric is shown in the figure (1). As the cone index increases, the wheel numeric increases where the soil strength has a great effect on wheel numeric by $48 \%$.

\section{(b) Effect of tire width}

The tire width is varied from 205 to $226 \mathrm{~mm}$ and all other parameters are fixed in Equations 1-7. The effect of tire width on all wheel numeric is shown in the figure (2), as the tire width increases, the wheel numeric increases where the tire width has a considerable effect on wheel numeric by $10 \%$.

\section{(c) Effect of tire diameter}

The tire diameter is varied from 657 to $776 \mathrm{~mm}$ and all other parameters are fixed in Equations 1-7. The effect of tire diameter on all wheel numeric is shown in the figure (3). As the tire diameter increases, the wheel numeric increases where the tire diameter has a considerable effect on wheel numeric by $20 \%$. 


\section{(d) Effect of tire weight}

The tire weight is varied from 2 to $7 \mathrm{kN}$ and all other parameters are fixed in Equations 1-7. The effect of tire weight on all wheel numeric is shown in the figure (4). As the weight on tire increases, the wheel numeric decreases where the tire weight has a great affect on wheel numeric by $70 \%$.

\section{(e) Effect of tire section height}

The tire section height is varied from 125 to $180 \mathrm{~mm}$ and all other parameters are fixed in Equations 1-7. The effect of tire section height on all wheel numeric is shown in the figure (5). As the tire section height increases, the wheel numeric decreases with $12 \%$.

\section{(f) Effect of tire deflection}

The tire deflection is varied from 1 to $25 \mathrm{~mm}$ and all other parameters are fixed in Equations 1-7. The effect of tire deflection $(\delta)$ on all wheel numeric is shown in the figure (6). As the tire deflection increases, the wheel numeric increases where the tire deflection has a great effect on wheel numeric by $70 \%$.

From Figures (1 to 6 ) three intervals of wheel numeric are obtained, the first for the Wismer and Luth wheel numeric $C_{n}$. The seconed interval for the Freitage $\left(N_{C}\right)$, Turnage $\left(\mathrm{N}_{\mathrm{Cl}}\right)$, Rowland, D \& Peel $\left(\mathrm{N}_{\mathrm{R}}\right)$, Maclaurin $\left(\mathrm{N}_{\mathrm{m}}\right)$ and the third interval for the Brixus wheel numeric $\left(B_{n}\right)$ which comes in the middle. These intervals lead to conclude that the most accurate range is the second intervals of the majority of wheel numeric for Freitage $\left(\mathrm{N}_{\mathrm{C}}\right)$, Turnage $\left(\mathrm{N}_{\mathrm{Cl}}\right)$, Rowland, D \& Peel $\left(\mathrm{N}_{\mathrm{R}}\right)$, Maclaurin $\left(\mathrm{N}_{\mathrm{m}}\right)$

All wheel numeric that published and introduced in equations (1- 7) which studied at different parameters has not included the effect of tire inflation pressure, so the main purpose of this paper is to investigate a new wheel numeric depending on the tire inflation pressure inside the tire deflection.

The author made some iteration using a tire inflation pressure; a new proposed wheel numeric's is investigated using Freitage wheel numeric for sand equation (2) is modified to be dimensionless with a new parameter, tire inflation pressure instead of tire deflection as follows:

$$
\begin{aligned}
\mathrm{C}_{\mathrm{nn}} & =\frac{5 \mathrm{CI} \sqrt{\mathrm{P}_{\mathrm{i}}}(\mathrm{b} \mathrm{d})^{\frac{3}{2}}}{7 \mathrm{~W}^{\frac{3}{2}}} \\
\mathrm{C}_{\mathrm{nn}} & =\frac{5 \frac{\mathrm{kN}}{\mathrm{m}^{2}} \sqrt{\mathrm{kPa}}\left(\mathrm{m}^{2}\right)^{\frac{3}{2}}}{7 \mathrm{kN}^{\frac{3}{2}}}=\frac{5 \frac{\mathrm{kN}}{\mathrm{m}^{2}} \sqrt{\frac{\mathrm{kN}}{\mathrm{m}^{2}}(\mathrm{~m})^{\frac{3}{3}}}}{7 \mathrm{kN}^{\frac{3}{2}}}=\frac{5}{7}=\mathrm{K}
\end{aligned}
$$

This formula is tested for different types of tires (shown in Appendix 1) and it gives good results on sand soil -using manufacture low inflation pressure on Sandcompared with Turnage [18] wheel numeric in equation (2) as in the Table 2.

The tire inflation pressure is varied from 100 to $250 \mathrm{kPa}$ and all other parameters are fixed in Equation 8. The effect of tire inflation pressure on the proposed wheel 
Table 2: Comparison of Turnage wheel numeric against proposed wheel numeric based on equation (8) and Appendix (1).

\begin{tabular}{|c|c|c|c|c|}
\hline Tire Size & $\begin{array}{c}\mathbf{P i} \\
\mathbf{( k P a )}\end{array}$ & $\begin{array}{c}\text { Turnage } \\
\left(\mathbf{N}_{\mathbf{C l}}\right)\end{array}$ & $\begin{array}{c}\text { Proposed } \\
\left(\mathbf{C}_{\mathbf{n n}}\right)\end{array}$ & $\begin{array}{c}\text { Accuracy } \\
\%\end{array}$ \\
\hline $900-13$ & $103-241$ & 5.221 & 5.35 & 97 \\
\hline $780-15$ & $82-206$ & 3.647 & 3.586 & 98 \\
\hline $750-16$ & $100-244$ & 2.665 & 3.045 & 88 \\
\hline $1200-18$ & $105-322$ & 3.448 & 4.144 & 83 \\
\hline $1250-20$ & $107-334$ & 3.377 & 3.968 & 85 \\
\hline
\end{tabular}

numeric is shown in the figure (7), as the tire inflation pressure increases, Wheel numeric increases. The variation of wheel numeric with the tire inflation pressure change is $57 \%$.

\section{MOBILITY EVALUATION (EMPIRICAL EQUATIONS)}

The following methods of evaluating the vehicle mobility using wheel mobility number have been reviewed.

Wismer \& Luth [5] developed the following widely used vehicle mobility equations for not highly compactable soils

- Motion resistance ratio:

$$
\mu_{\mathrm{mrr}}=\frac{\mathrm{RR}}{W}=\frac{1.2}{\mathrm{C}_{\mathrm{m}}}+0.04
$$

- Torque ratio:

$$
\mu_{t r}=\frac{T}{r * W}=0.75\left(1-e^{-0.3 C_{n} I^{2}}\right)
$$

- $\quad$ Net traction ratio (Pull ratio):

$$
\mu_{\mathrm{ntr}}=\frac{\mathrm{NT}}{\mathrm{W}}=\mu_{\mathrm{tr}}-\mu_{\mathrm{mrr}}=0.75\left(1-e^{-0.3 \mathrm{C}_{\mathrm{n}} \mathrm{s}^{2}}\right)-\left(\frac{1.2}{\mathrm{C}_{\mathrm{n}}}+0.04\right)
$$

- Tractive efficiency:

$$
\mathrm{TE}=\left[\frac{\frac{N T}{W}}{\frac{\mathrm{T}}{\mathrm{r} \cdot \mathrm{W}}}\right](1-\mathrm{s})=\frac{\mu_{\mathrm{ntr}}}{\mu_{\mathrm{tr}}}(1-\mathrm{s})=\frac{\mu_{\mathrm{ntr}}}{\mu_{\mathrm{ntr}}+\mu_{\mathrm{mm}}}(1-\mathrm{s})
$$

These equations are valid for the following situations:

$$
\frac{b}{d} \approx 0.3, \quad \frac{\delta}{h} \approx 0.2, \quad \frac{r}{d} \approx 0.475
$$


- Wismer \& Luth mobility number (Cn)-modified:

$\mathrm{C}_{\text {nw }}=\frac{\mathrm{CInbd}}{\mathrm{W} \cdot \mathrm{TDF}}$

where: TDF ..... Tire deflection factor.

- This can be calculated from the following equation:

$$
\operatorname{TDF}=\sqrt{\left[\frac{1-\frac{\delta}{h}}{0.8}\right]^{3}}
$$

Ashmore [21] added a term (W/Wr) to Wismer and Luth type equations to predict log-skidder tire performance.

- Motion resistance ratio:

$$
\mu_{\text {mIr }}=\frac{\mathrm{RR}}{\mathrm{W}}=-0.1\left(\frac{\mathrm{W}}{\mathrm{W}_{r}}\right)+\frac{0.22}{\mathrm{C}_{n}}+0.2
$$

- Torque ratio:

$$
\mu_{\mathrm{sr}}=\frac{\mathrm{T}}{\mathrm{r} * \mathrm{~W}}=0.47\left(1-e^{-0.2 c_{\mathrm{n}} \mathrm{s}}\right)+0.28\left(\frac{\mathrm{W}}{\mathrm{W}_{\mathrm{r}}}\right)
$$

- Net traction ratio:

$$
\mu_{\mathrm{ntr}}=\frac{\mathrm{P}}{\mathrm{W}}=\mu_{\mathrm{tr}}-\mu_{\mathrm{mrr}}=0.38\left(\frac{\mathrm{W}}{\mathrm{W}}\right)+0.47\left(1-e^{-0.2 \mathrm{C}_{\mathrm{n}} \mathrm{s}}\right)-\frac{0.22}{\mathrm{C}_{\mathrm{n}}}-0.2
$$

Gee-Glough [6- 7] found out, that soil shear strength was somewhat correlated with penetration resistance, and added a soil shear factor into the model.

- Motion resistance ratio:

$$
\mu_{\operatorname{mrr}}\left(\mathrm{C}_{\mathrm{R}}\right)=\frac{\mathrm{RR}}{\mathrm{W}}=0.049+\frac{0.287}{N_{C I}}
$$

- Net traction ratio:

$$
\mu_{\text {ntr }}\left(C_{T}\right)=\mu_{n t_{\max }}\left(1-e^{-k s}\right)
$$

Where: $\mu_{\text {ntrax }}\left(C_{\text {T.max }}\right) \ldots .$. Maximum coefficient of net traction ratio

$$
\begin{gathered}
\mu_{\text {ntr } \max }\left(\mathrm{C}_{\mathrm{T} \max }\right)=0.796-\frac{0.92}{N_{C l}} \\
\mathrm{k}=\frac{4.838+0.061 \mathrm{~N}_{\mathrm{Cl}}}{\mathrm{C}_{\mathrm{T} \max }}
\end{gathered}
$$

- Tractive efficiency: 


$$
\mathrm{TE}=\frac{\mu_{\mathrm{ntr}}}{\mu_{\mathrm{tr}}}(1-\mathrm{s})=\frac{\mu_{\mathrm{ntr}}}{\mu_{\mathrm{ntr}}+\mu_{\mathrm{mrr}}}(1-\mathrm{s})
$$

Dwyer [22- 23] developed expressions for coefficient of rolling resistance and net traction at $20 \%$ slip, and maximum traction coefficient.

- Motion resistance ratio:

$$
\mu_{\text {mrr }}=\frac{\mathrm{RR}}{W}=0.05+\frac{0.287}{N_{C I}}
$$

- Torque ratio:

$$
\mu_{\mathrm{sr}}=\frac{\mathrm{T}}{\mathrm{r} * \mathrm{~W}}=0.796-\frac{0.92}{N_{C I}}
$$

- net traction ratio at $20 \%$ wheel slip:

$$
\mu_{\text {ntr }}=\frac{\mathrm{P}}{\mathrm{W}}=\left(0.796-\frac{0.92}{N_{C I}}\right) \cdot\left(1-\mathrm{e}^{-\left(4.898+0.061 . \mathrm{N}_{\mathrm{CI}}\right) .5}\right)
$$

Brixus [8-9] developed a more generalized expression for tractive characteristics of bias-ply pneumatic tires. Their approach is based on a modified mobility number which it called $\mathrm{Bn}$

- Motion resistance ratio:

$$
\mu_{\mathrm{mrs}}=\frac{\mathrm{RR}}{\mathrm{W}}=\frac{1}{\mathrm{~B}_{\mathrm{n}}}+\frac{0.5 \mathrm{~s}}{\sqrt{\mathrm{B}_{\mathrm{n}}}}+0.04
$$

Where:

- Torque ratio:

$$
\mathrm{B}_{\mathrm{n}}=\frac{\mathrm{CI} \mathrm{bd}}{\mathrm{W}}\left(\frac{1+\frac{5 \delta}{\mathrm{h}}}{1+\frac{3 \mathrm{~b}}{\mathrm{~d}}}\right)
$$

$$
\mu_{\mathrm{tg}}=\frac{\mathrm{T}}{\mathrm{r} * \mathrm{~W}}=0.88\left(1-e^{-0.1 \mathrm{~B}_{\mathrm{n}}}\right)\left(1-e^{-0.75 \mathrm{~g}}\right)+0.04
$$

- Net traction ratio:

$$
\mu_{\mathrm{ntr}}=\frac{\mathrm{NT}}{\mathrm{W}}=\mu_{\mathrm{tr}}-\mu_{\operatorname{mrr}}=0.88\left(1-e^{-0.1 \Xi_{\mathrm{n}}}\right)\left(1-e^{-0.75 \mathrm{~s}}\right)-\left(\frac{1}{\mathrm{~B}_{\mathrm{n}}}+\frac{0.5 \mathrm{~s}}{\sqrt{\mathrm{B}_{\mathrm{n}}}}\right)
$$

Rowland \& Peel [15] developed WES modelling, and extended it also for tracked vehicles. He presented the concept of mean maximum pressure, MMP, which is the maximum allowable calculated soil contact pressure at no-go situation.

- Motion resistance ratio:

$$
\mu_{\operatorname{mrr}}=\frac{\mathrm{RR}}{\mathrm{W}}=3(1+5) N_{R}^{-2,7}
$$

where: 
$\mathrm{N}_{\mathrm{R}}=\frac{\mathrm{CI} \cdot \mathrm{b}^{0.85} \cdot \mathrm{d}^{0.15}}{\mathrm{~W}} \sqrt{\frac{\delta}{\mathrm{h}}}$

- Net traction ratio:

$$
\mu_{\mathrm{ntr}}=\frac{\mathrm{p}}{\mathrm{W}}=0.12 \mathrm{~N}_{\mathrm{R}}^{0.88}\left(1-0.61(1-\mathrm{s})^{\frac{4}{4}}\right)
$$

Upaduhaya [24-25] developed a new technique for evaluating the vehicle mobility factor without a wheel numeric but taking in consideration the effect of tire inflation pressure

- Net traction ratio:

$$
\mu_{\mathrm{ntr}}=\frac{\mathrm{NT}}{\mathrm{W}}=\mathrm{a}\left(1-\mathrm{e}^{-\mathrm{cs}}\right)
$$

- Gross traction ratio:

$$
\mu_{\mathrm{gtr}}=\frac{\mathrm{T}}{\mathrm{r} * \mathrm{~W}}=\mathrm{a}^{*}\left(1-\mathrm{b}^{\mathrm{a}} \mathrm{e}^{\mathrm{es}}\right)
$$

where:

$$
\begin{aligned}
& a, c, a^{\prime}, b^{\prime}, c^{\prime} \quad \text { soil, tire and loading coefficient as follows: } \\
& c=c^{\prime}
\end{aligned}
$$

The analytical plot of net traction ratio and traction efficiency of all empirical methods using real data on has shown in figures $(8,9)$. From Figs, the range of net traction ratio (Pull ratio) for the case study is $0.4-0.6$ at maximum point and the tractive efficiency at maximum point is $0.45-0.65$.

Then for vehicle mobility evaluation the pull ratio is compared. Net traction ratio is a dimensionless number that indicates the vehicle's towing ability, by using the new wheel numeric the vehicle mobility (net traction ratio) have been predicted.

The plot of the new proposed wheel numeric based on equation (9) with the pull ratio is shown in figure (10). From Fig., the maximum point of pull ratio at 0.5 which considered in optimum range when compared with the published by Abdel-Barry [20] a good correlation is found with one constrain of using the off road inflation pressure given by tire manufacture manual in Appendix 1. 


\section{CONCLUSION}

The different parameters affecting wheel numeric has been investigated. As the weight on tire increases, the wheel numeric decreases where the tire weight has a great affect on wheel numeric by $70 \%$. Also as tire section height increases, the wheel numeric decreases with $12 \%$. The soil strength has a great affect on wheel numeric where as soil strength increases, the wheel numeric increases by $48 \%$. Also as the tire deflection increases, the wheel numeric increases. The tire deflection has a great affect on wheel numeric by $70 \%$. While the tire diameter has a considerable affect on wheel numeric by $20 \%$. The tire width has a considerable affect on wheel numeric by $10 \%$. The effect of tire inflation pressure on the proposed wheel numeric has been investigated where the tire inflation pressure has a great affect on wheel numeric by $57 \%$.

A case study is carried out using experimental tire testing parameters to investigate a new wheel numeric based on tire inflation pressure. The results are compared with results given by other wheel numerics; a good correlation has been obtained. The theoretical vehicle performance in terms of net traction ratio and tractive efficiency versus slip has been predicted based on proposed wheel numeric and Brixius tractive equations which are most commonly used and accepted by the ASAE Standards. Fig (10) shows the theoretical results which are compared with published data; there is a good agreement between them.

\section{REFERENCES}

[1] Bekker, M. G. "Off-the-road locomotion", research and development in terramechanics. University of Michigan Press, Ann Arbor. 220 s, 1960

[2] Bekker, M. G. "Introduction to terrain-vehicle systems". University of Michigan Press, Ann Arbor. 846 s, 1969

[3] Freitag, D.R. "A dimensional analysis of performance of pneumatic tires in soft soils", WES Technical report No3-688, 1965.

[4] Turnage, G. W. "Tire selection and performance prediction for off-road wheeled-vehicle operations", Proceedings of the 4th International ISTVS Conference, Stockholm-Kiruna, Sweden, April 24-28, 1972. I:62- 82, 1972.

[5] Wismer, R.D. \& Luth, H. J. "Off-road traction prediction for wheeled vehicles", Transaction ASAE 17(1):8-10.14, 1973.

[6] Gee-Clough. D. "A comparison of the mobility number and Bekker approaches to the traction mechanics and recent advances in both methods at the N.I.A.E." Proceedings of the 6th International ISTVS conference, Vienna, Austria, August 22-25, 1978. II:735-755, 1978.

[7] Gee-Clough. D. "Selection of tire sizes for agricultural vehicles", Journal of agricultural engineering research 25(3):261-278, 1980.

[8] Brixius, W. W. "Traction prediction equations for bias ply tires", ASAE paper No 87-1622, 1987. 
[9] Brixius, W. W. \& Wismer, R. D. "Traction prediction for wheeled vehicles", John Deere Report No109, 1975.

[10] Maclaurin, E. B. "The effect of tread pattern on the field performance of tires", Proceedings of the 7th International ISTVS Conference, August 16-20. 1981, Calgary, Canada. II:699-735, 1981.

[11] Maclaurin, E. B. "The use of mobility numbers to describe the in-field tractive performance of pneumatic tires". Proceedings of the 10th International ISTVS Conference, Kobe, Japan, August 20-24, 1990. I: 177-186, 1990.

[12] Maclaurin E. B. "The use of mobility numbers to predict the tractive performance of wheeled and tracked vehicles in soft cohesive soils", Proceedings of the 7th European ISTVS Conference, Ferrara, Italy, 8-10. October 1997:391-398, 1997.

[13] Maclaurin E. B. "Comparing the NRMM (VCI), MMP and VLCI traction models", Journal of Terramechanics 43-51, 2007.

[14] Rowland, D. "Tracked vehicle ground pressure and its effect on soft ground performance", Proceedings of the 4th International ISTVS Conference April 2428.1972, Stockholm-Kiruna, Sweden. I:353-384, 1972.

[15] Rowland, D \& Peel, J. W. "Soft ground performance prediction and assessment for wheeled and tracked vehicles", Institute of mechanical engineering 205:81, 1975.

[16] Turnage, G. W. "Using dimensionless prediction terms to describe off-road wheel vehicle performance", ASAE Paper No. 72-634, 1972 b.

[17] Turnage, G. W. "A synopsis of tire design and operational considerations aimed at increasing in soil tire drawbar performance". Proceedings of the 6th International ISTVS Conference, Vienna, Austria, August 22-25, 1978, II:757810, 1978.

[18] Turnage, G. W. "Prediction of in-sand tire and wheeled vehicle drawbar performance", Proceedings of the 8th International ISTVS Conference, Cambridge, UK, 6-10 July 1984, I:121-150, 1984.

[19] Abdel Bary A. M. "Optimization of tire-soil interaction related to off-road vehicle performance", PhD thesis, Helwan University (Faculty of engineering - Mataria), 2003

[20] Abdel Bary A. M. , Mahmoud M. \& Selim A. M. "Development of a single wheel testing for tires tractive performance testing on Egyptian soils", $7^{\text {th }}$ AMME conference (MTC), May-1996

[21] Ashmore, C., Burt, C. \& Turner, J. "An empirical equation for predicting tractive performance of log skidder tires", Transactions of the ASAE, 30(5):1231-1236, 1987

[22] Dwyer, M. J "Tractive performance of a wide, low-pressure tire compared with conventional tractor drive tires", Journal of terramechanics $24(3): 227-234$, 1987.

[23] Dwyer, M. J. "Tractive performance of wheeled vehicles", Journal of Terramechanics 21(1):19-34, 1984. 
[24] Upadhyaya, S. K., Wulfsohn, D. and Jubbal, G., "Traction prediction equations for radial ply tires". Journal of Terramechanics, 26(2), 149 175, 1989.

[25] Upadhyaya, S. K. \& Wulfsohn, D. "Traction prediction for radial ply tires", Proceedings of the 10th International ISTVS Conference, Kobe, Japan, August 20-24, 1990. II: 447-451, 1990.

[26] M. Saarilahti, "Evaluation of the WES-Method in Assessing The Trafficability of Terrain and the Mobility of Forest Tractors", PART 1, WES mobility models, University of Helsinki, Department of Forest Resource Management, , 2002

[27] Transport \& engineering Co. (TRENCO), Manufacture Tire catalog, www.trenco-tire.com.eg. 


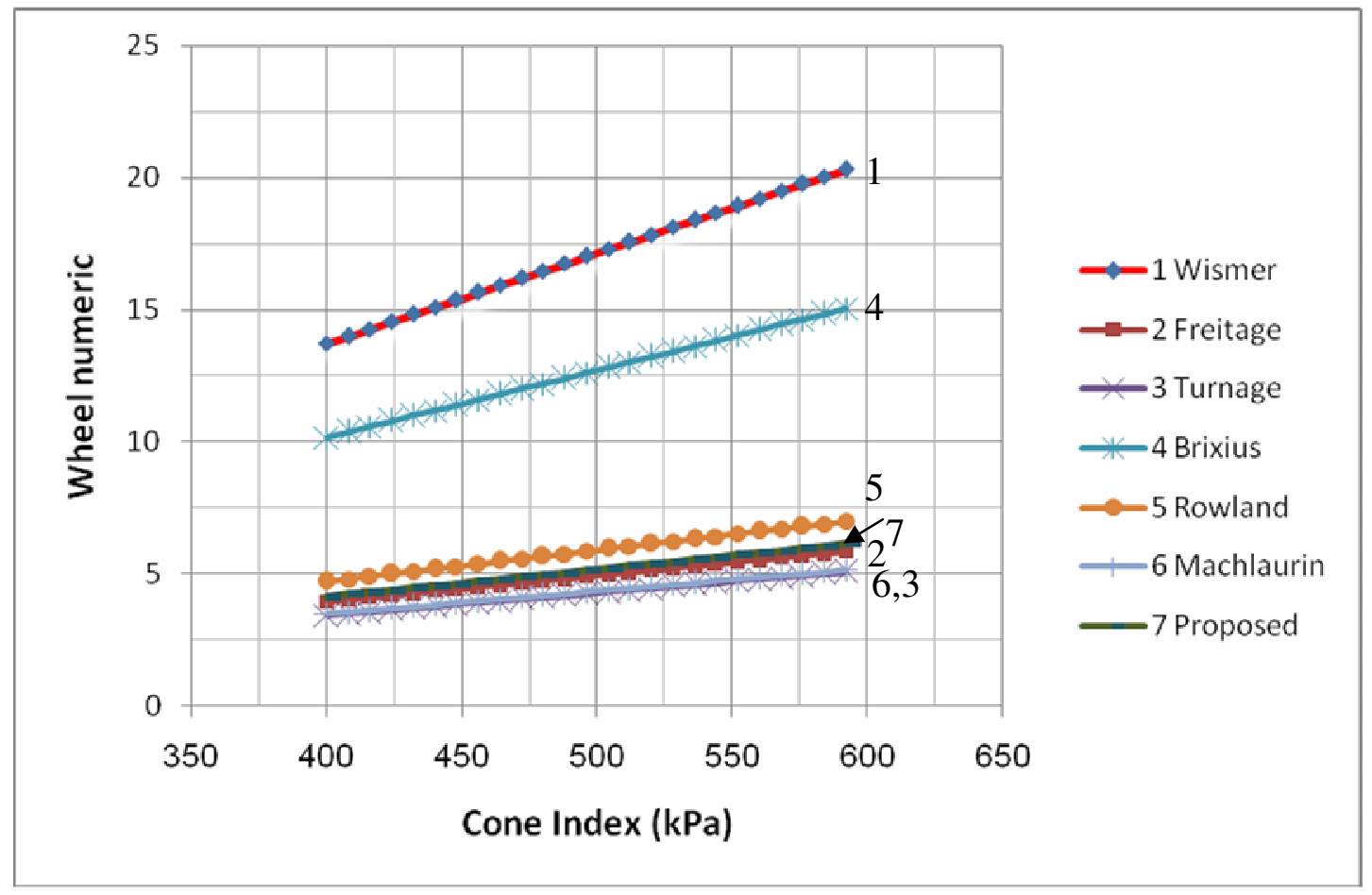

Fig. 1. Variation of wheel numeric with soil cone index.

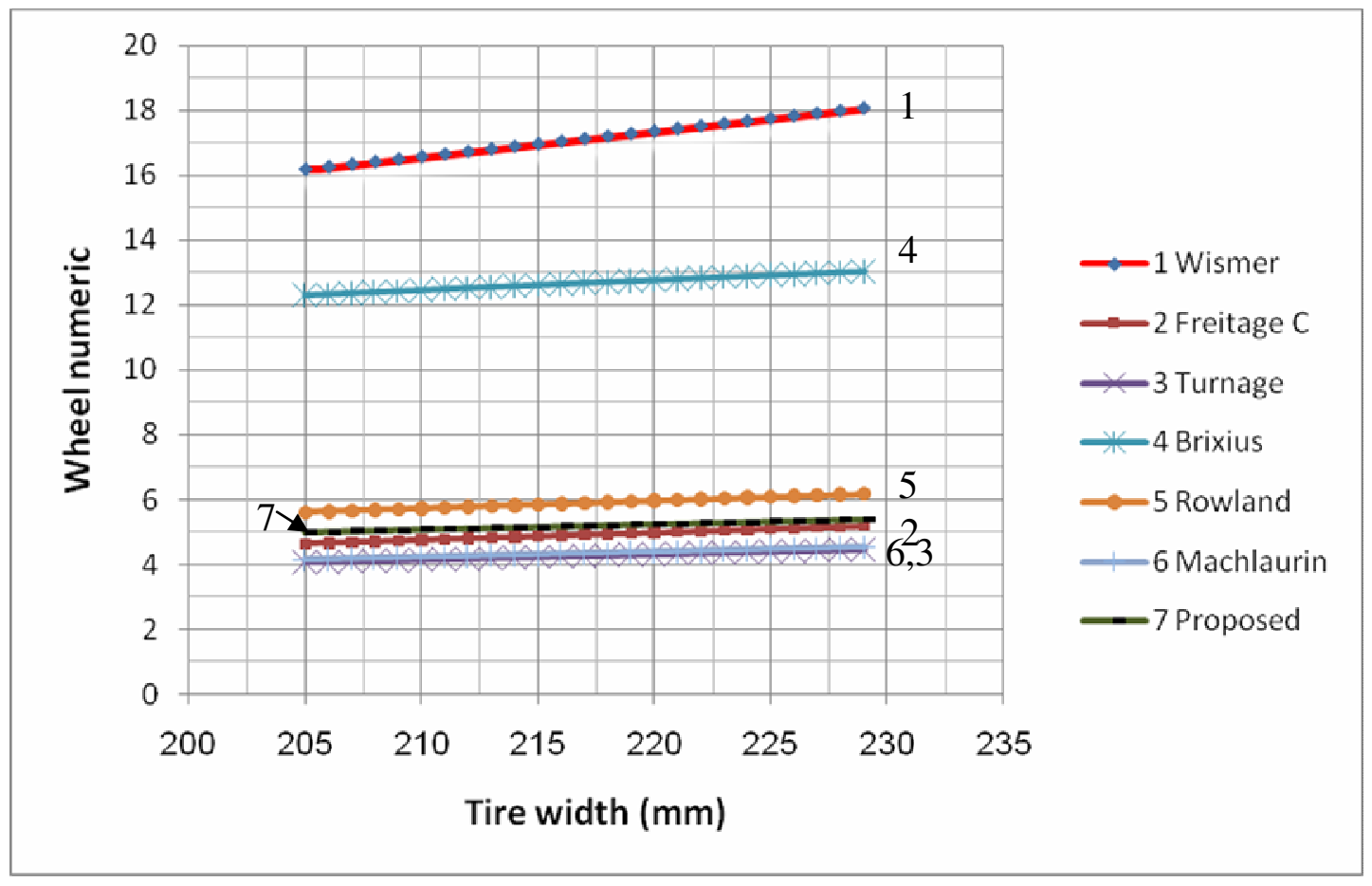

Fig. 2. Variation of wheel numeric with tire width. 


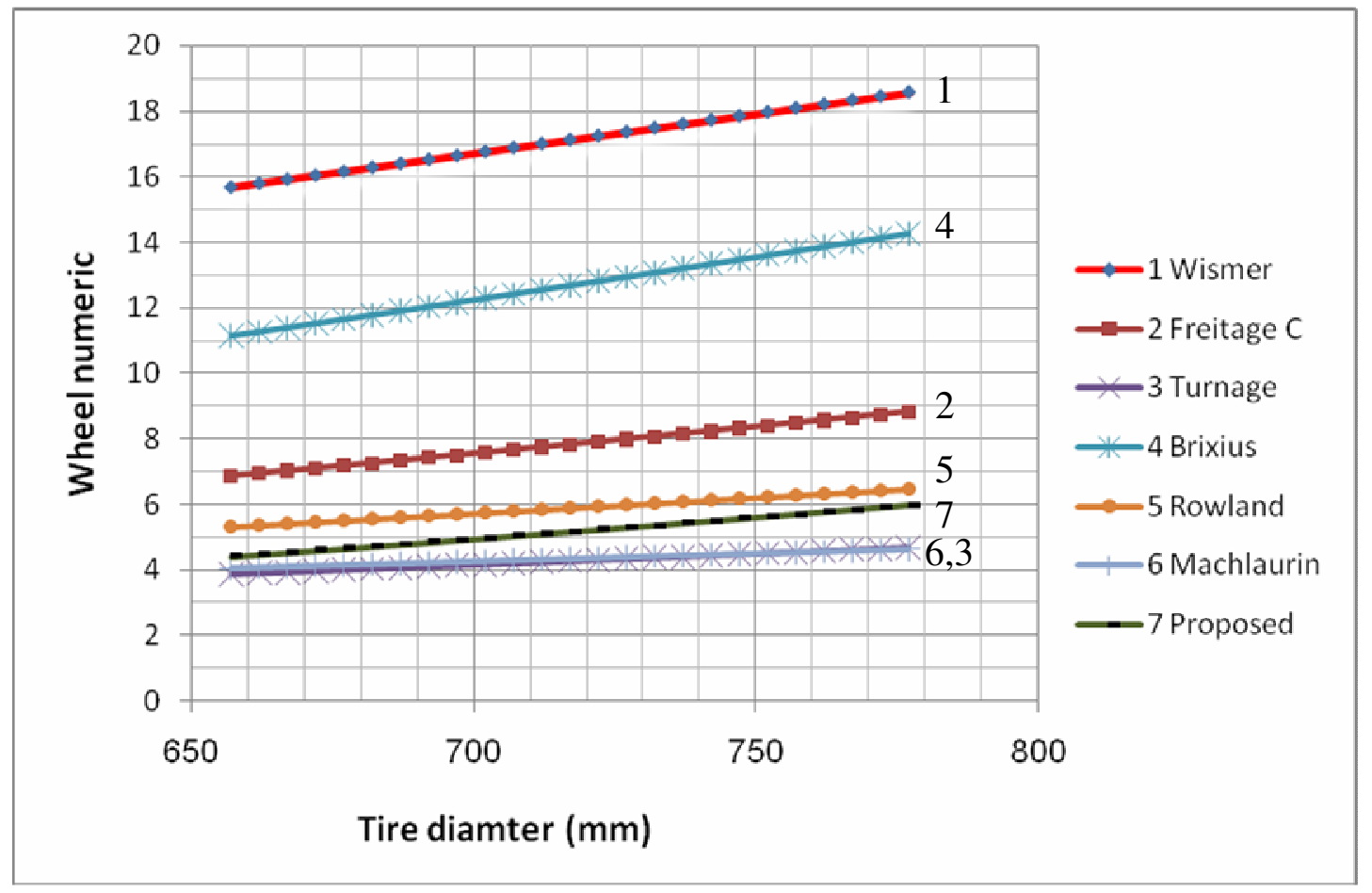

Fig. 3. Variation of wheel numeric with tire diameter.

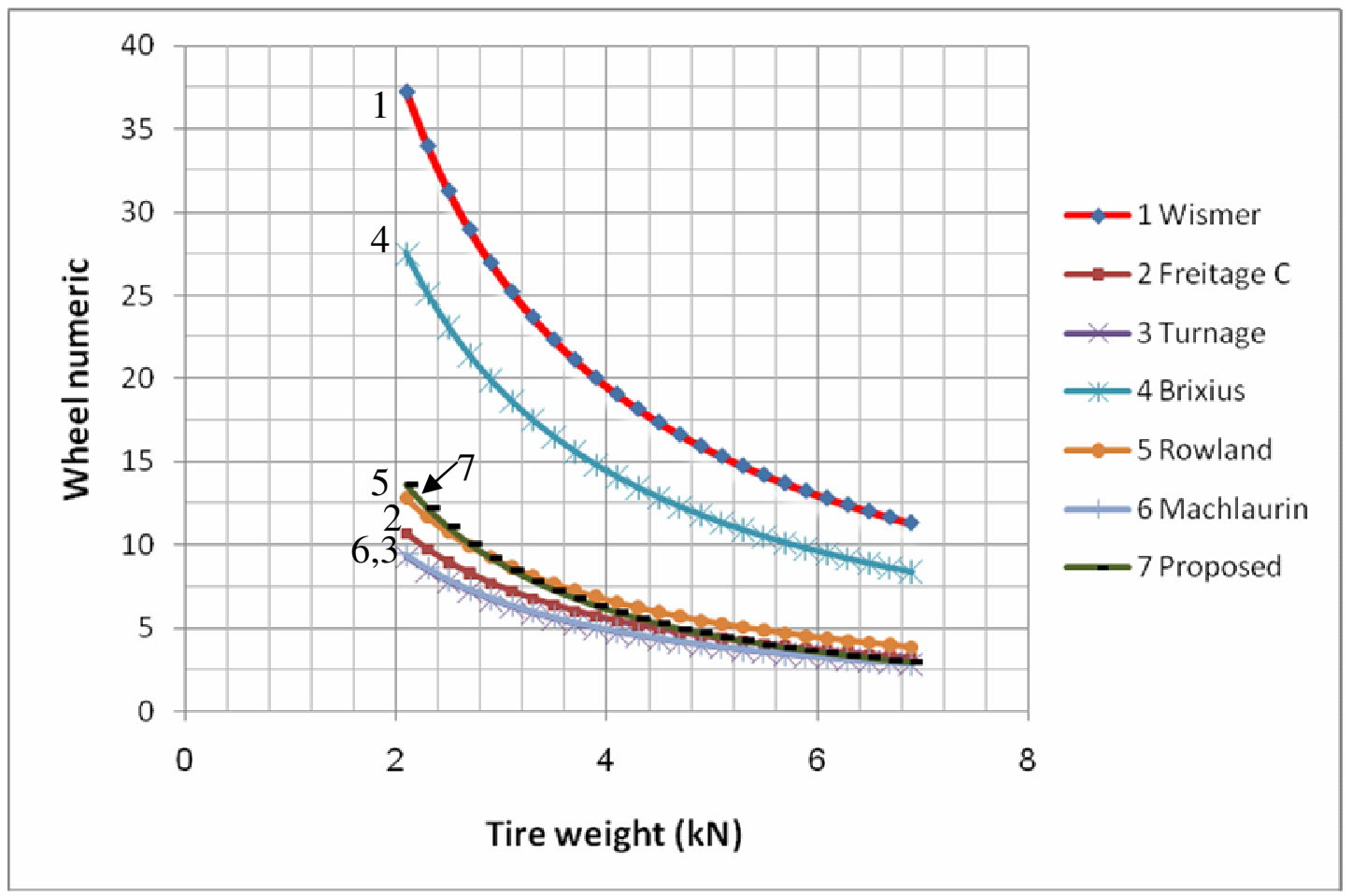

Fig. 4. Variation of wheel numeric with tire weight. 


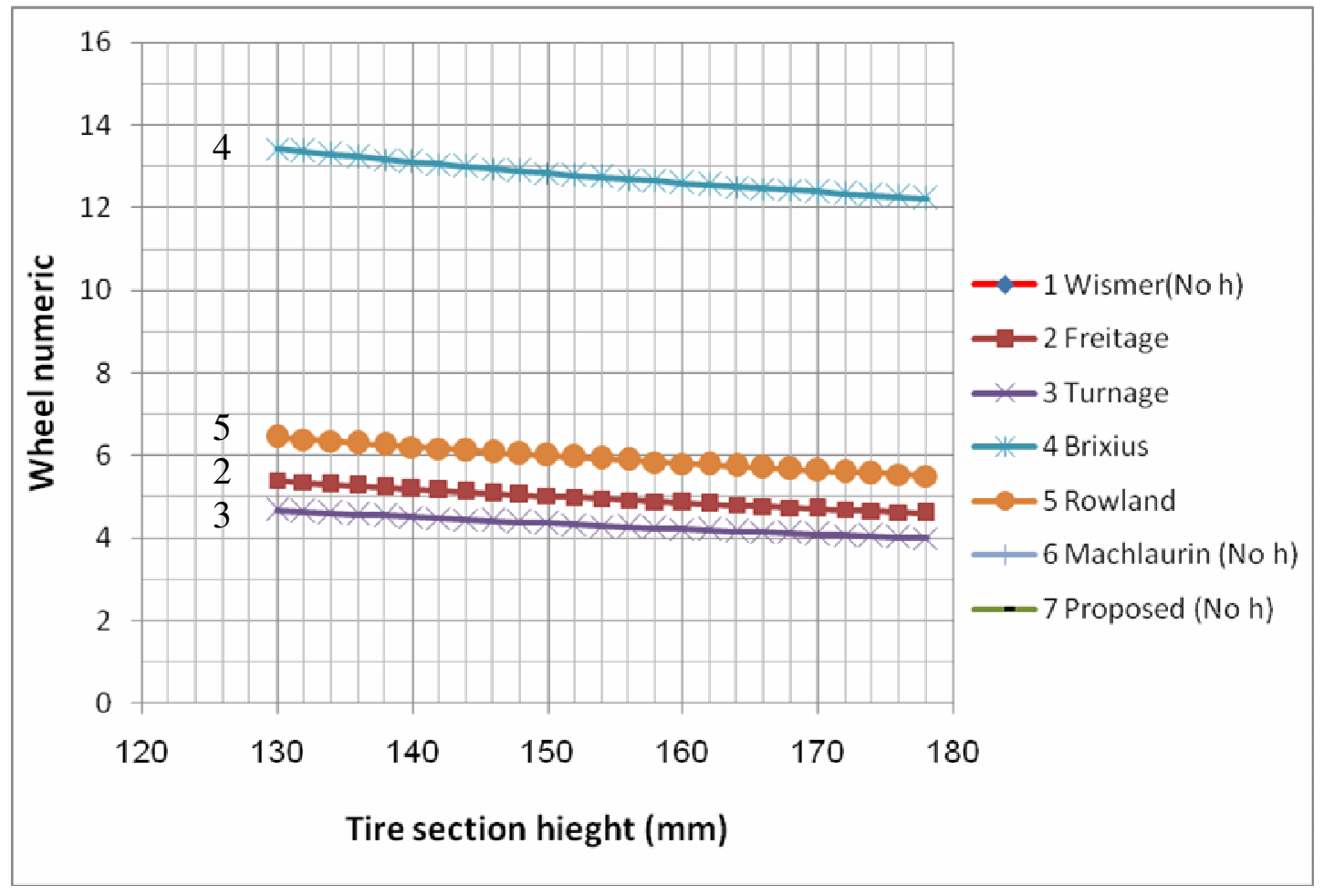

Fig. 5. Variation of wheel numeric with tire section height.

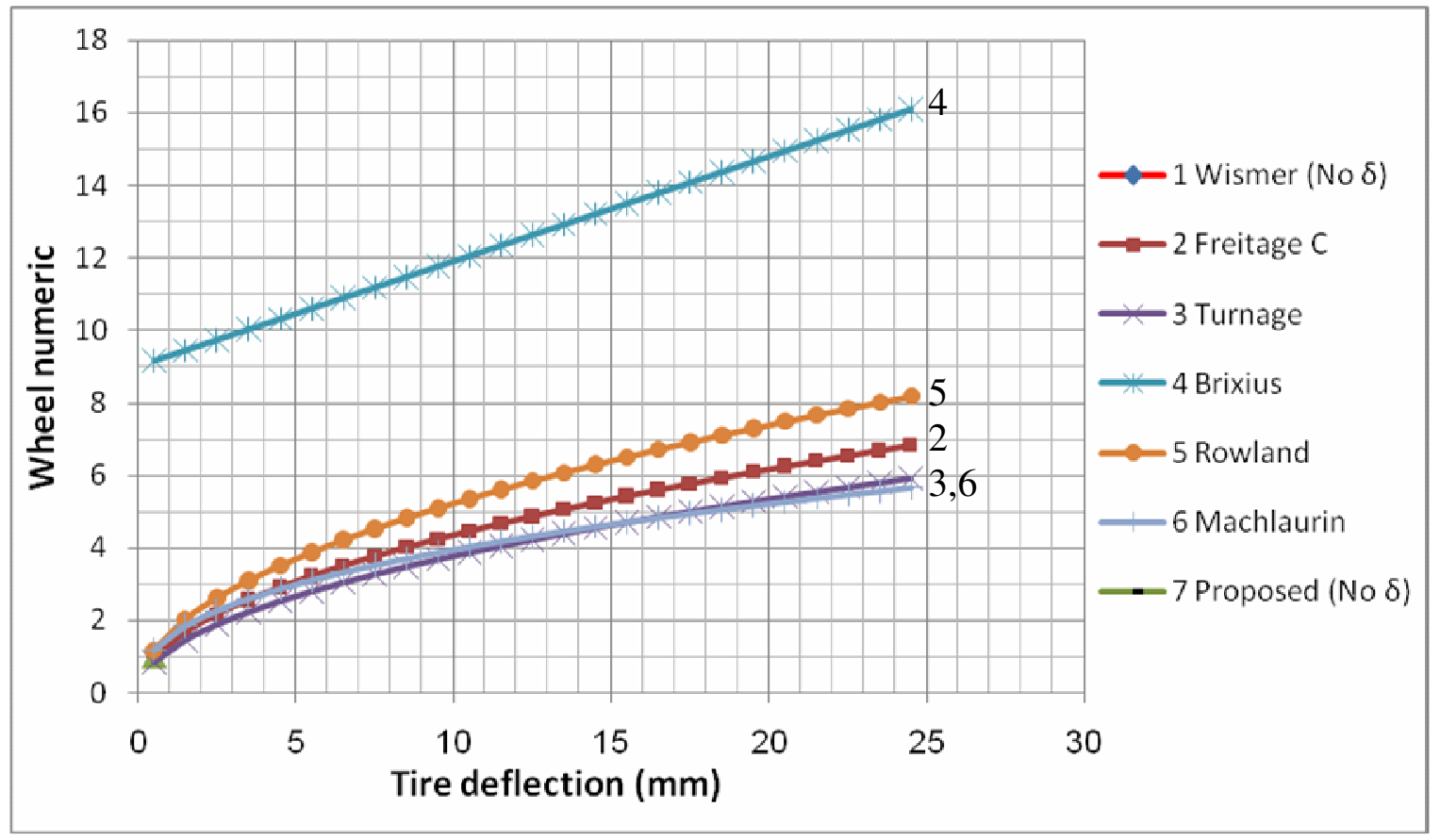

Fig.6. Variation of wheel numeric with tire deflection. 


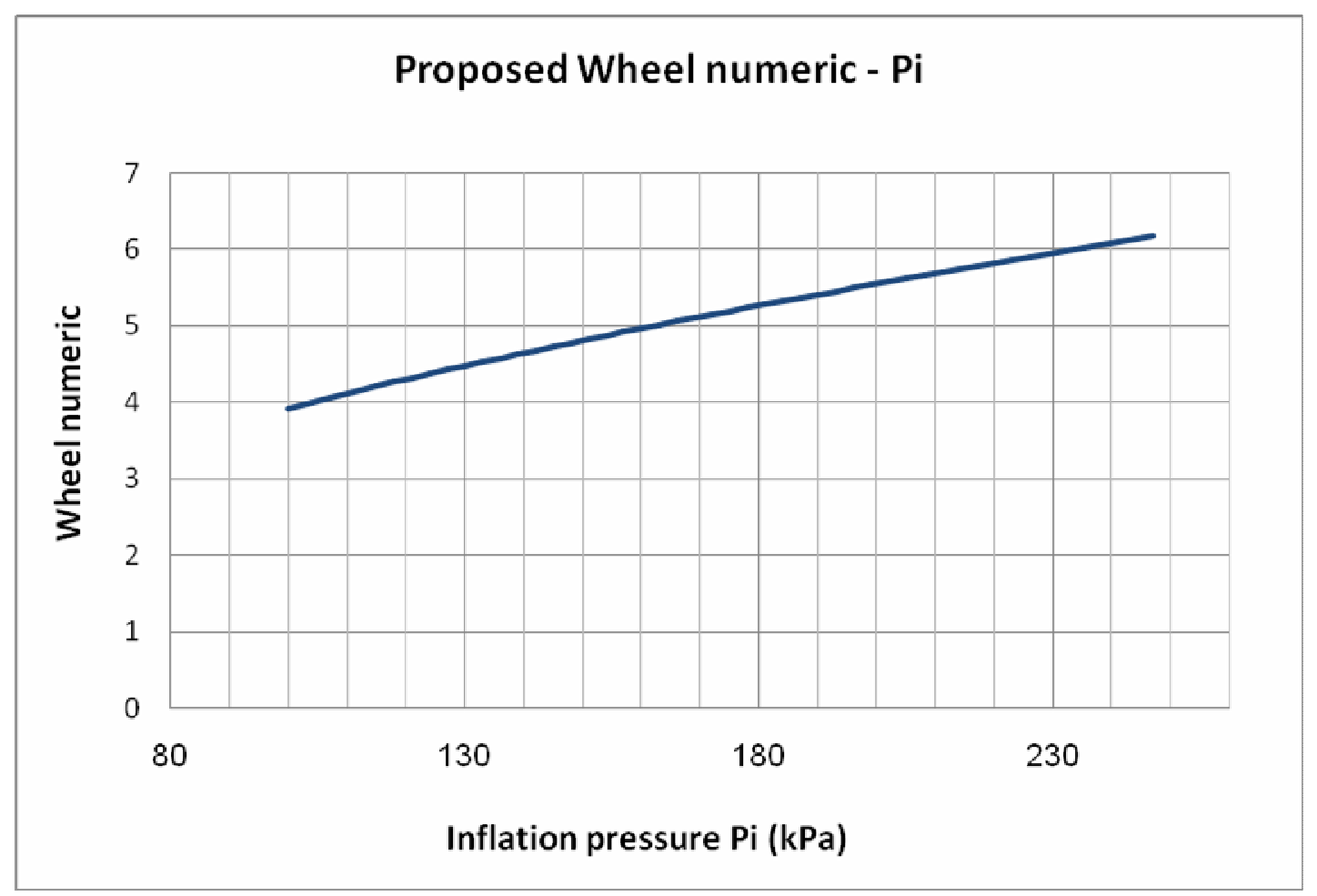

Fig.7. Variation of wheel numeric with tire inflation pressure.

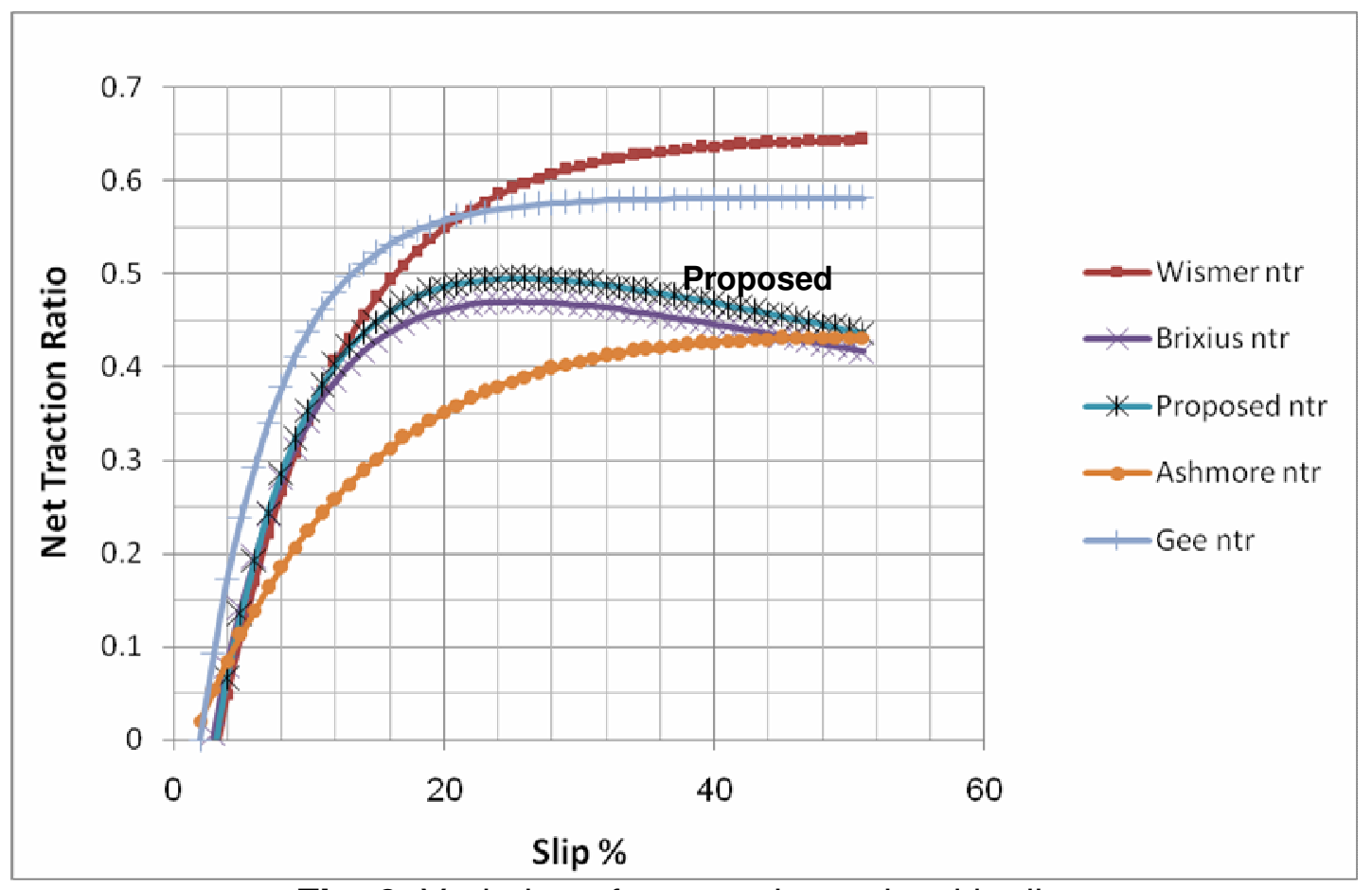

Fig. 8. Variation of net traction ratio with slip. 


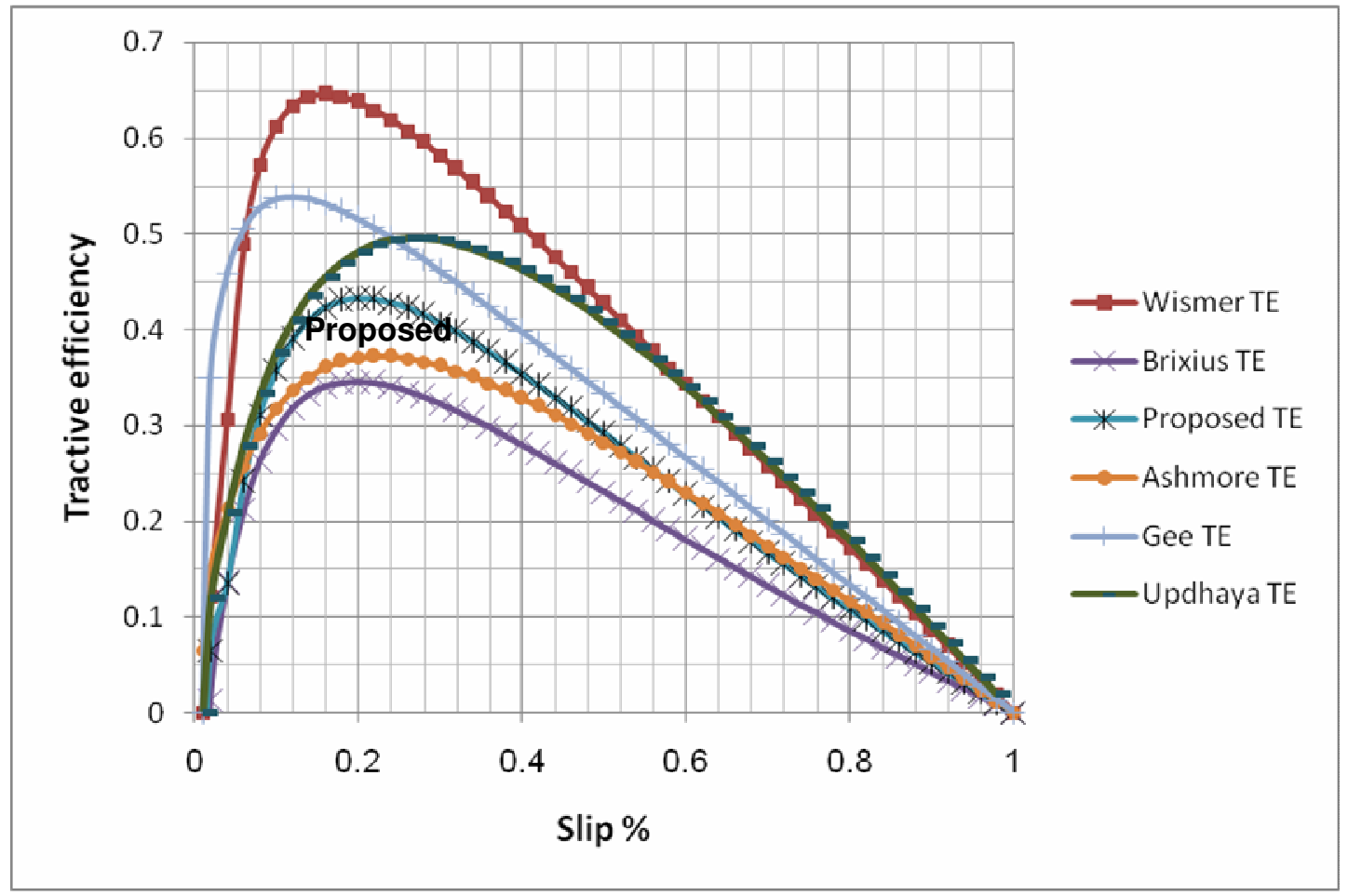

Fig. 9. Variation of tractive efficiency with slip.

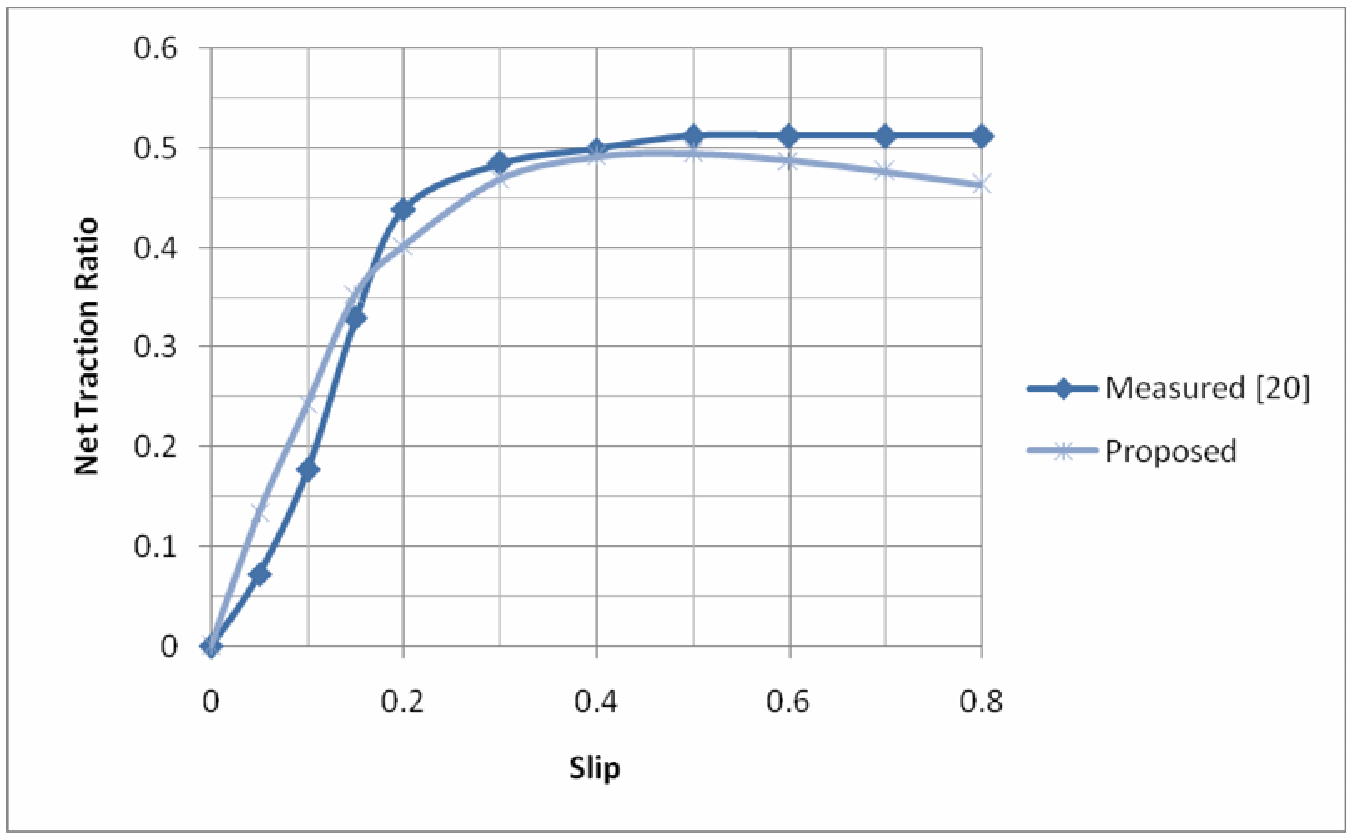

Fig. 10. Variation of net traction ratio with slip. 
Appendix 1: Tire geometry from manufacture [27].

\begin{tabular}{|c|c|c|c|c|c|c|c|c|c|c|c|c|c|c|}
\hline Type & \multicolumn{4}{|c|}{ Low speed on soft sand } & \multicolumn{4}{|c|}{ High speed } & & & & & \multicolumn{2}{|c|}{ S.L.R } \\
\hline \multirow{3}{*}{$1200-18$} & \multicolumn{2}{|c|}{$\begin{array}{l}\text { Inflation } \\
\text { pressure }\end{array}$} & \multicolumn{2}{|c|}{ Max load } & \multicolumn{2}{|c|}{$\begin{array}{l}\text { Inflation } \\
\text { pressure }\end{array}$} & \multicolumn{2}{|c|}{ Max load } & \multicolumn{2}{|c|}{$\begin{array}{c}\text { Section } \\
\text { width }\end{array}$} & \multicolumn{2}{|c|}{$\begin{array}{l}\text { Overall } \\
\text { diamter }\end{array}$} & \multicolumn{2}{|c|}{$\begin{array}{c}\text { Static } \\
\text { Radius }\end{array}$} \\
\hline & Psi & $\mathrm{kPa}$ & $\mathrm{kg}$ & $\mathrm{kN}$ & Psi & $\mathrm{kPa}$ & $\mathrm{kg}$ & $\mathrm{kN}$ & $\mathrm{mm}$ & in & $\mathrm{mm}$ & in & $\mathrm{mm}$ & in \\
\hline & 17 & 117.2 & 1850 & 18.14 & 80 & 551.6 & 2650 & 25.98 & 281 & 11.08 & 1081 & 42.56 & 475 & 18.72 \\
\hline \multirow{3}{*}{$1250-20$} & \multicolumn{2}{|c|}{$\begin{array}{l}\text { Inflation } \\
\text { pressure }\end{array}$} & \multicolumn{2}{|c|}{ Max load } & \multicolumn{2}{|c|}{$\begin{array}{l}\text { Inflation } \\
\text { pressure }\end{array}$} & \multicolumn{2}{|c|}{ Max load } & \multicolumn{2}{|c|}{$\begin{array}{c}\text { Section } \\
\text { width }\end{array}$} & \multicolumn{2}{|c|}{$\begin{array}{l}\text { Overall } \\
\text { diamter }\end{array}$} & \multicolumn{2}{|c|}{$\begin{array}{c}\text { Static } \\
\text { Radius }\end{array}$} \\
\hline & Psi & $\mathrm{kPa}$ & $\mathrm{kg}$ & $\mathrm{kN}$ & Psi & $\mathrm{kPa}$ & $\mathrm{kg}$ & $\mathrm{kN}$ & $\mathrm{mm}$ & in & $\mathrm{mm}$ & in & $\mathrm{mm}$ & in \\
\hline & 20 & 137.9 & 1315 & 12.9 & 50 & 344.7 & 2000 & 19.61 & 284 & 11.38 & 1026 & 40.38 & 459 & 18.06 \\
\hline \multirow{3}{*}{$750-16$} & \multicolumn{2}{|c|}{$\begin{array}{l}\text { Inflation } \\
\text { pressure }\end{array}$} & \multicolumn{2}{|c|}{ Max load } & \multicolumn{2}{|c|}{$\begin{array}{l}\text { Inflation } \\
\text { pressure }\end{array}$} & \multicolumn{2}{|c|}{ Max load } & \multicolumn{2}{|c|}{$\begin{array}{l}\text { Section } \\
\text { width }\end{array}$} & \multicolumn{2}{|c|}{$\begin{array}{l}\text { Overall } \\
\text { diamter }\end{array}$} & \multicolumn{2}{|c|}{$\begin{array}{c}\text { Static } \\
\text { Radius }\end{array}$} \\
\hline & Psi & $\mathrm{kPa}$ & $\mathrm{kg}$ & $\mathrm{kN}$ & Psi & $\mathrm{kPa}$ & $\mathrm{kg}$ & $\mathrm{kN}$ & $\mathrm{mm}$ & in & $\mathrm{mm}$ & in & $\mathrm{mm}$ & in \\
\hline & 15 & 103.4 & 620 & 6.08 & 58 & 399.9 & 950 & 9.13 & 208 & 9.2 & 785 & 30.9 & 353 & 13.8 \\
\hline \multirow{3}{*}{$780-15$} & \multicolumn{2}{|c|}{$\begin{array}{l}\text { Inflation } \\
\text { pressure }\end{array}$} & \multicolumn{2}{|c|}{ Max load } & \multicolumn{2}{|c|}{$\begin{array}{l}\text { Inflation } \\
\text { pressure }\end{array}$} & \multicolumn{2}{|c|}{ Max load } & \multicolumn{2}{|c|}{$\begin{array}{l}\text { Section } \\
\text { width }\end{array}$} & \multicolumn{2}{|c|}{$\begin{array}{l}\text { Overall } \\
\text { diamter }\end{array}$} & & $\begin{array}{l}\text { atic } \\
\text { dius }\end{array}$ \\
\hline & Psi & $\mathrm{kPa}$ & $\mathrm{kg}$ & $\mathrm{kN}$ & Psi & $\mathrm{kPa}$ & $\mathrm{kg}$ & $\mathrm{kN}$ & $\mathrm{mm}$ & in & $\mathrm{mm}$ & in & $\mathrm{mm}$ & in \\
\hline & 15 & 103.4 & 460 & 4.51 & 36 & 248.2 & 690 & 6.77 & 211 & 8.32 & 725 & 28.5 & 326 & 12.83 \\
\hline & & $\begin{array}{l}\text { ation } \\
\text { sure }\end{array}$ & & load & & $\begin{array}{l}\text { ation } \\
\text { sure }\end{array}$ & & load & & tion & & $\begin{array}{l}\text { rall } \\
\text { ter }\end{array}$ & & tius \\
\hline 00010 & Psi & $\mathrm{kPa}$ & $\mathrm{kg}$ & $\mathrm{kN}$ & Psi & $\mathrm{kPa}$ & $\mathrm{kg}$ & $\mathrm{kN}$ & $\mathrm{mm}$ & in & $\mathrm{mm}$ & in & $\mathrm{mm}$ & in \\
\hline & 15 & 103.4 & 685 & 6.72 & 35 & 241.3 & 960 & 9.41 & 234 & 9.2 & 800 & 31.5 & 351 & 13.8 \\
\hline
\end{tabular}

